\title{
The Role of Permitting Regimes in Western United States Groundwater Management
}

\author{
$+$ \\ by Rebecca Nelson ${ }^{1}$ and Debra Perrone ${ }^{2}$ \\ ${ }^{1}$ Corresponding Author; University of Melbourne; Melbourne Law School; Room 942, Level 9, \\ 185; Pelham Street; Carlton VIC 3053 Australia; +61 38344 0436; \\ rebeēca.nelson@unimelb.edu.au \\ ${ }^{2}$ Western Water Dashboard Project; Water in the West Stanford University; 473 Via Ortega, \\ Room 216; Stanford, CA 94305; 650-724-7609
}

\section{()}

Across the western United States (West), groundwater management takes an infinite variety of forms, one of which is regulation. Regulatory tools structure rights and impose some mandatory measure of control over groundwater use. Underlying many regulatory tools is the quantification of legal rights to withdraw groundwater, in order to pursue the following objectives: facilitate the rights being managed or traded; make sure that users do not exceed their rights; and protect rightholders, as well as the sustainability of the resource as a whole, from the adverse impacts of pumping. "Permitting" is a regulatory approach that requires would-be pumpers to seek permission from a government agency to withdraw groundwater through a formal process designed to pursue the aforementioned objectives.

Permitting regimes provide an important foundation for managing groundwater in many western states. Across the West, the geographic reach of permitting regimes is expanding (Nelson and This is the author manuscript accepted for publication and has undergone full peer review but has not been through the copyediting, typesetting, pagination and proofreading process, which may lead to differences between this version and the Version of Record. Please cite this article as doi: 10.1111/gwat.12467

This article is protected by copyright. All rights reserved. 
Perrone 2016). It is in this context that comparative analyses focused on western states' permitting regimes would complement existing literature focused on groundwater governance (e.g., Varady et al. 2013; Bryner and Purcell 2003; Gerlak et al. 2013; Blomquist et al. 2004; Megdal et al. 2015) and groundwater law concepts (e.g., Weeks 2010; Spiegel 2010; Richardson 2012; Reiblich and Klein 2013-2014).

$=$

(

Because of the growing importance of permitting for successful and sustainable groundwater management, we focus on an overview of (i) permitting, (ii) its distinctiveness from the common law, and (iii) its adoption across the West. Although groundwater law concepts can be similar across the West, it is important to keep in mind the local variability of the law. Just as hydrogeology can vary significantly across regions, so can permitting regimes and the common law. Our discussion here addresses permitting and the common law in general terms, acknowledging but not discussing the detail of state differences.

\section{What is Permitting?}

\section{Permitting requires a would-be pumper to gain permission to withdraw groundwater. A} permitting regime goes beyond, and complements, a system for authorizing the drilling of wells. Regimes usually take legal form in state statutes or in ordinances promulgated by local agencies that are granted permitting powers by state statutes. Permits to withdraw groundwater can be defined by, for example, the extraction rate, location, and type of use, and certain categories of use can be excused from permitting requirements through exemptions. Permitting regimes 
usually include criteria to be considered by the decision-maker to ensure that the proposed withdrawal will, for example, avoid adverse impacts on existing wells and surface water right holders, fulfil a beneficial use, and be in the public interest. Informational tools like metering and monitoring requirements, and financial or other sanctions for non-compliance usually accompany the permit criteria (Nelson and Perrone 2016).

Permitting regimes and "good" science go hand-in-hand. Permitting regimes rely on the availability of scientific information about the likely impacts of a proposed withdrawal to determine whether a particular permit may be granted. This assessment of the sustainability of a proposed withdrawal before it is permitted helps prevent adverse impacts before the impacts can manifest. Permitting regimes usually include tools for reducing withdrawals that are found to be produce unacceptable impacts, even after the permit has been granted. In these ways, permitting systems are the foundation for assessing, maintaining, and recovering the sustainability of groundwater basins. Permitting regimes also help secure social and economic sustainability by protecting pumping-infrastructure investments with legally defensible and certain rights.

\section{Permitting vs Common Law}

Although groundwater law is as old as the settlement of the West itself, statutory groundwater permitting regimes are more recent innovations. Old-style regimes for managing groundwater, which relied purely on the common law, proved sub-optimal in many places. Permitting regimes were introduced, and now usually complement and extend common law concepts. Permitting

This article is protected by copyright. All rights reserved. 
regimes have at least three major advantages over pure common law regimes for managing rights to withdraw groundwater, as we explain below.

\section{Permitting regimes may significantly broaden the concept of basin-wide sustainability beyond the relatively narrow focus of pure common law regimes. Under the common law, $=$ basin-wide total groundwater extraction is limited to the "safe yield." Safe yield is defined as the volume of water "that can be extracted each year from an aquifer on a renewable basis"} (Thompson et al. 2013). This volumetric characteristic is usually the main relevant consideration.

By contrast, permitting regimes may view sustainability more comprehensively in terms that can include aspects relating to water quality, connected surface water, and impacts on the land surface and dependent ecosystems, in addition to more familiar impacts of extraction on groundwater storage and levels. In other words, when passing groundwater statutes, state legislatures can make sure that basin-wide limits on groundwater withdrawals are informed by modern concerns that go beyond traditional ideas about safe yield. Indeed, historically, concepts have struggled to accommodate scientifically accurate views of sustainable levels of withdrawal and regard for impacts on connected surface waters and groundwater dependent ecosystems (Alley and Leake 2004).

\section{Permitting regimes may refer to broader concepts when balancing individual rights to} groundwater than have been considered under the common law. Looking beyond basin-level 
extraction limits, a key part of any legal system for managing groundwater withdrawals incorporates principles to reconcile competing individual rights to the resource. Under the common law, those individual rights are limited by reference to concepts that differ depending on the common law doctrine that applies. The "first in time, first in right" doctrine of prior appropriation applies in most western states (Bryner and Purcell 2003). Prior appropriation has a relatively narrow focus on protecting pre-existing rights, that is, reconciling competing uses in a way that favors longer-established uses. By contrast, permitting regimes may consider broader matters, outside those that are relevant to the common law, or even alter key common law considerations (Benson 2012). These include principles of equity, efficiency, or socially preferred water uses. Such principles appear in permitting regimes in lists of criteria that a decision-maker must consider when determining whether to grant a permit for a groundwater withdrawal. Unlike the common law, a statute may also allow for varying the principles that apply in different geographic locations, to suit local preferences.

\section{Permitting requires prior review and approval of withdrawals, whereas pure common law regimes rely solely on judicial resolution of disputes that arise between pumpers after pumping has become established. The common law allows one to acquire a right simply by starting to pump, and applying the water to a beneficial use. No entity must first grant its permission, and no entity scrutinises the proposal against the applicable basin-wide use limits or other rules, or determines what the likely impacts will be on neighboring water users before pumping commences. Equally, no entity quantifies the pumper's resulting water right before}


pumping commences - a key prerequisite to resolving subsequent disputes between pumpers (Foley-Gannon 2008). For common law rules that protect sustainability and other pumpers to take real-world effect, common law rules require a groundwater user to file a potentially expensive and time-consuming lawsuit to settle all the groundwater rights in a basin (basin "adjudications"). In some states, this happens relatively rarely (Nelson 2012). The resulting lack of supervision has the potential to lead to unrestrained pumping in practice, regardless of what the law says about safe yield on paper. Permitting regimes import a level of supervision of the effects of groundwater use in areas of intensive extraction that is more difficult to achieve under the common law. While the common law approach may work well at low levels of development, such an approach becomes more difficult to sustain without running into problems where groundwater users, once few and dispersed, become numerous and concentrated.

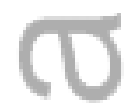

\section{Permitting in the West}

All 17 western U.S. states have now introduced the concept of a groundwater permitting regime into their state groundwater laws. Some states were early adopters-New Mexico created its first groundwater code in 1927 (Hall 2008). California was the last to incorporate a widely applicable groundwater withdrawal permitting power (though this power did previously exist in some smaller geographic areas known as special districts) when its Legislature passed the Sustainable Groundwater Management Act (SGMA) of 2014, which has yet to take effect fully. The power that SGMA grants local agencies to require groundwater withdrawal permits is one of its unsung strengths (Nelson and Perrone 2016). In some cases, permitting regimes are 
central parts of the state's overall groundwater management system, as in the regimes administered by the State Engineer in New Mexico and the Department of Natural Resources and Conservation in Montana. In other cases, a permitting regime appears to be conceived of as merely a supplementary management tool to be taken up at the option of local governments, as in the SGMA permitting power in California and its equivalent in Texas.

\section{Some permitting regimes are explicitly linked to comprehensive groundwater management}

plans. The permitting regime can serve as an important method of implementing an overall local or regional management plan, which also often includes supply-side and other demand-side measures for groundwater management. This is true at the local level in relation to the groundwater sustainability plans adopted by California groundwater sustainability agencies and Texas groundwater conservation district management plans. Permitting practices are also linked to the achievement of the goals of management plans for Active Management Areas in Arizona's state-led governance structure. The practice of linking permitting regimes to management plans is not unique to the American West. Australia and European countries have also adopted systems that view permitting as an integral part of an overall planned approach to groundwater management (Nelson and Quevauviller 2016).

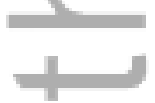

Even on preliminary data, we see a great degree of diversity among western U.S. permitting regimes (Nelson and Perrone 2016). States invest different types of agencies at different levels of government with permitting powers. Those powers apply to different 
categories of groundwater use, across geographic areas that differ greatly between western states. Permitting regimes differ in the extent to which they require those powers to be used, and most importantly, in the considerations that apply to their exercise, and the metering, monitoring and enforcement tools that support those powers. The significant diversity of permitting arrangements provides a laboratory of regulatory arrangements, the examination of which holds great promise for identifying elements for effectively supporting sustainable groundwater management. Additional work comparing permitting regimes can help to identify opportunities to use particular permitting tools that are present, but under-appreciated, in another jurisdiction (Brand 2006-2007). Such work can also highlight tools that appear only rarely in written laws, but may be useful to consider introducing outside their home jurisdictions (Brand 2006-2007).

\section{Concluding Thoughts}

Significant recent research points to ongoing and sometimes worsening groundwater depletion, both from a technical perspective (Konikow 2015) and from the perspective of state agency officials (Megdal et al. 2015). This suggests an ever-increasing need to connect elements of governance structures, such as permitting, with trends in physical conditions. Regardless of precisely how a state considers groundwater permitting, it is clear that the role of permitting regimes as a groundwater management solution is increasing in importance across the West. The questions remain simple, though the answers may be complex: which permitting tools are working, where, and why?

This article is protected by copyright. All rights reserved. 


\section{References}

Alley, W.M. and Leake, S.A. 2004. The Journey from Safe Yield to Sustainability. Groundwater 42 no. 1:12-16.

Benson, R.D. 2012. Alive But Irrelevant: The Prior Appropriation Doctrine in Today's Western Water Law. University of Colorado Law Review. 83: 675-714.

Blomquist, W.A., E. Schlager, and T. Heikkila. 2004. Common Waters, Diverging Streams: Linking Institutions to Water Management in Arizona, California, and Colorado: RFF Press.

Brand, O. 2006-2007. Conceptual Comparisons: Towards a Coherent Methodology of Comparative Legal Studies. Brooklyn Journal of International Law 32: 405-466.

Bryner, G., and E. Purcell. 2003. Groundwater Law Sourcebook of the Western United States. Natural Resources Law Center, University of Colorado School of Law.

Foley-Gannon, E. 2008. Institutional Arrangements for Conjunctive Water Management in California and Analysis of Legal Reform Alternatives. Hastings West-Northwest Journal of Environmental Law \& Policy 14: 1105.

Gerlak, A.K., S.B. Medgal, R.G. Varady, and H. Richards. 2013. Groundwater Governance in the U.S. Groundwater Governance in the U.S.: Summary of Initial Survey Results.

Hall, G.E. 2008. First 100 Years of the New Mexico Water Code, The Essay. Natural Resources Journal 48: 245.

Konikow, L.F. 2015. Long-Term Groundwater Depletion in the United States. Groundwater 53 no. $1: 2-9$. 
Megdal, S.B., A.K. Gerlak, R.G. Varady, and L.-Y. Huang 2015. Groundwater Governance in the United States: Common Priorities and Challenges. Groundwater 53 no. 5: 677-684.

Nelson, R. 2012. Assessing Local Planning to Control Groundwater Depletion: California as a Microcosm of Global Issues. Water Resources Research 48 no 1: W01502.

Nelson, R. and D. Perrone. 2016. Local Groundwater Withdrawal Permitting Laws in the SouthWest US: California in Comparative Context. Groundwater 54 no. 6: xxx-xxx.

Nelson, R.) and P. Quevauviller. 2016. Groundwater Law. In Integrated Groundwater Management ed. T. Jakeman, O. Barreteau, R. Hunt and J.-D. Rinaudo, 173-196. Springer Publishing.

Reiblich, J., and C.A. Klein. 2013-2014. Climate Change and Water Transfers. Pepperdine Law Review 41: 439-508.

Richardson, J.J. 2012. Existing Regulation of Exempt Wells in the United States. Journal of Contemporary Water Research \& Education 148 no. 1: 3-9.

Spiegel, D. 2010. Can the Public Trust Doctrine Save Western Groundwater? New York University Environmental Law Journal 18: 412-453.

Thompson Jr, B.H., J.D. Leshy, and R. Abrams. 2013. Legal Control of Water Resources: Cases and Materials, 7th edn, West Publishing.

Varady, R.G., F.v. Weert, S.B. Megdal, A. Gerlak, C.A. Iskandar, and L. House-Peters. 2013. Groundwater Policy and Governance. Global Environment Facility and U.N. Food and Agriculture Organisation. 
Weeks, A. 2010. Defining the Public Interest: Administrative Narrowing and Broadening of the Public Interest in Response to the Statutory Silence of Water Codes. Natural Resources Journal 50: 255-289.

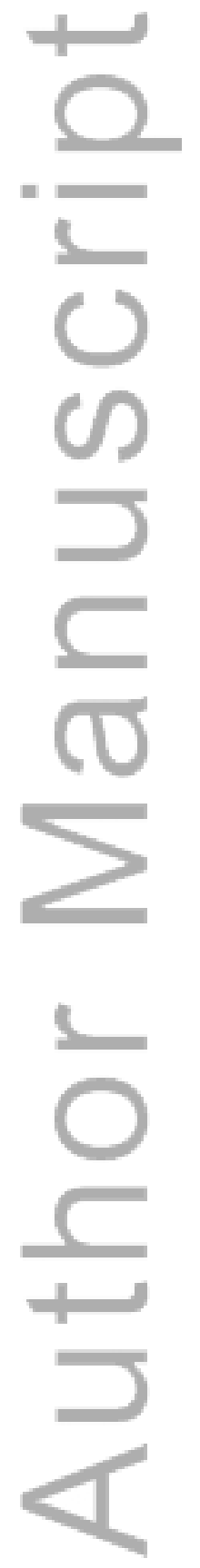




\section{University Library}

\section{- M M I N E R VA A gateway to Melbourne's research publications}

Minerva Access is the Institutional Repository of The University of Melbourne

Author/s:

Nelson, R;Perrone, D

Title:

The Role of Permitting Regimes in Western United States Groundwater Management.

Date:

2016-11

Citation:

Nelson, R. \& Perrone, D. (2016). The Role of Permitting Regimes in Western United States Groundwater Management.. Ground Water, 54 (6), pp.761-764. https://doi.org/10.1111/ gwat. 12467.

Persistent Link:

http://hdl.handle.net/11343/291840 